\title{
II. Dünya Savaşı Yıllarında Türkçü Dergiciliğin Bir Örneği Olarak Gök-Börü Dergisi ${ }^{1}$
}

\author{
Murat Karataş $^{2}$ \\ Abdullah Gül University, Dr, Department of History, Kayseri,Turkey \\ Received- Accepted: 13.02.2019-18.03.2019 \\ Research Article
}

\section{Öz}

Bu makalede, II. Dünya Savaşı ylllarında Reha Oğuz Türkkan tarafindan 5 Kasım 1942 - 23 Mayıs 1943 tarihleri arasında İstanbul'da 13 sayı olarak yayımlanan Gök-Börü dergisi konu edilmiş̧ir. Derginin yayımlandığı̆ dönemdeki en önemli özelliği Türkiye'de rrkçlığa dayanan bir milliyetçilik algısı oluşturmaya çalşması olmuştur. Bu anlamda dergi, öncüleri Ergenekon ve Bozkurt'taki gibi “Her Irkın Üstünde Türk Irkı" logosuyla Türklerin kendine has ve üstün olduğunu anlatmaya çalışmış ayrıca Batı emperyalizmine karşı Türk milletini içinde bulunduğu maddi ve manevi çöküs halinden kurtarmanın yolunun ırkçllktan geçtiğini dile getirmiştir. Gök-Börü dergisinde tarih, edebiyat, sosyoloji, iktisat ve rrkçılık üzerine makaleler, şirler ve karikatürler yer almaktadır. Ağrllklı olarak Türkkan'ın yazilarnın yer aldığ dergide, dönemin Türkçü ilim ve fikir adamlarnndan başka ilerleyen yıllarda Türk siyasi hayatında yer tutacak Nuri Demirağ ve Bülent Ecevit de kendilerine yer bulmuştur. Bu çalışmada Gök-Börü dergisi şekil ve içerik olarak ele alınmıştır. Derginin II. Dünya Savaşı yıllarnnda çıkmış olmasının getirdiği siyasi ve psikolojik alt yapının yazilara nasıl yansıdığına, dergide yer alan yazılardan hareketle dönemin toplumsal havasına dair tespitlerde bulunulmuştur. Gök-Börü’de ırkçıllk düşüncesi dışında Türkiye haricindeki Türklere dönük ilgiye dikkat çekilmiştir. Elde ettiğimiz veriler ışı̆ğnda II. Dünya Savaş yıllarında Türkiye’de toplum tabanında Türklerin kendine has ve üstün olduğu aynıca Türkiye haricindeki Türklere dönük ilginin yer bulduğu sonucuna varılmıştır.

Anahtar Kelimeler: II. Dünya Savaşı, Gök-Börü, Reha Oğuz Türkkan, Irkçıllk, Dış Türkler.

\section{Gök-Börü Magazine As An Example Of Turkish Magazine During The World War II}

\begin{abstract}
This article is about Gök-Börü Magazine which was published as 13 issues between 5th October 1942 and 23rd May 1943 by Reha Oğuz Türkkan during the Second World War. During its publishment period the most important point was that it had an attempt to create a perception of nationalism based on racism in Turkey. In this sense as in the Bozkurt and Ergenekon the pioneer of the magazine, it attempted to tell that Turkish are unique and higher with the loop of "Turkish Race Is Higher Than Every Race". Furthermore, they uttered that against the Western imperialism, racism was the only way to save the Turkish people from material and moral collapse they were in. There were articles about history, literature, sociology, economy and racism in the Gök-Börü Magazine. Turkish science and idea men of this period Bülent Ecevit and Nuri Demirağ who were going to take part in the Turkish political life in the future found place in the magazine in which predominantly Türkan's writings took part in this work we are going to handle the Börü Magazine with its shape and content. From the point of these writings of the magazine we are going to determine the social atmosphere of the period and how psychological and political substructure were reflected during the Second World War. Apart from the idea of racism in Gök-Börü, we are going to attract the attention to the interest of the Turkish people living except from Turkey. In the light of this information we are going to determine that during the World War II Turkish people had its own unique and superior qualifications among society and also there was an interest to the Turkish people who were abroad Turkey.
\end{abstract}

Keywords: World War II, Gök-Börü, Reha Oğuz Türkkan, Racism, Foreign Turkish.

\footnotetext{
${ }^{1}$ Bu makale, 11-14 Mayıs 2017 tarihlerinde Türklerin Dünyası Enstitüsü’nce Antalya’da düzenlenen Uluslararası Türklerin Dünyası Sempozyumu'nda sunulan bildirinin gözden geçirilmiş halidir.

*This article is analyzed by two reviewers and it is screened for the resembalance rate by the editor. (Bu makale iki hakem tarafindan incelenmiş ve editör tarafindan benzerlik oranı taramasından geçirilmiştir)

${ }^{2}$ murat.karatas@agu.edu.tr, ORCID: 0000-0003-1174-5828.
} 


\section{Giriş}

Türkiye Cumhuriyeti'nin kuruluşu ile birlikte tanımlama güçlüğü çekilen düşünce biçimlerinin başında milliyetçilik gelmiştir. Mustafa Kemal Atatürk döneminde dış ve iç şartların zorlamasıyla milliyetçilikle ilgili farklı fikri yaklaşım ve uygulama biçimi ortaya çıkmıştır. Bu anlamda dışarıda 1929 Dünya ekonomik krizi içeride Serbest Cumhuriyet Fırka denemesinin başarısızlığı Türkiye'de devlet aklını yeni bir evreye taşımıştır. Devletin kültürel ve siyasi hayatı denetimi altına alma çabası Türk Ocakları'nın kapatılması sonucunu doğurmuş̧ur. Bu gelişme ise II. Meşrutiyet ile iktidar olan Türkçülük düşüncesinin, devletin kurucu ideolojisi olma özelliğini yitirmesi ve muhalefete düşmesi anlamına gelmiştir.

Mustafa Kemal Atatürk’ün vefatından sonra başlayan Milli Şef/ İsmet İnönü dönemi II. Dünya Savaşı'nın da etkisiyle içerideki fikri hayatı dış politikada sorun çıkarmaması için çok sıkı kontrol altına almıştır. Bu dönemde devlet açısından en sorunlu ideolojik grup Türkçüler olmuştur. Bunlara göre başta Almanya olmak üzere demokrasi ile yönetilen Batılı devletler ve Rusya; Türkiye'nin üzerinde emperyalist emelleri olan devletlerdi. Bu bakış açısı dış politikada denge siyaseti izleyen İnönü için onları sorun haline getirmiştir.

Gök-Börü dergisinin öncüleri Ergenekon ve Bozkurt dergileridir. Reha Oğuz Türkkan tarafindan Mustafa Kemal Atatürk'ün vefat ettiği gün çıkartılan Ergenekon dergisi ancak dört sayı çıkabilmiş ve sonunda faşizm aleyhine yazılar nedeniyle hükümet tarafindan kapatılmıştır (Koçlar, 2013, s. 263). Dışarıda II. Dünya Savaşı'nın yoğun bir şekilde Almanlar lehine devam ettiği içeride de TBMM kürsüsünden Başbakan Şükrü Saraçoğlu'nun yüksek perdeden Türkçü olduklarım haykırdığı atmosfer, dönemin en dikkate değer tarafidır.

Böyle bir atmosferde Gök-Börü'nün Ergenekon'dan sonraki öncülü olan Bozkurt dergisi Reha Oğuz Türkkan tarafindan çıkartılmıştır. Ancak Türkçülüğün temel meseleleriyle ilgili Hüseyin Nihal Atsı ile yaşadığı tartışmalar Türkkan ve çevresinin Bozkurt'tan tasfiyeleriyle sonuçlanmıştır. Bundan kısa süre sonra da Türkkan tarafindan Gök-Börü dergisi hem Türkçülük düşüncesinin liderliğini üstlenmek hem de ülkede ırkçılığa dayalı bir milliyetçilik algısı oluşturmak amacıyla çıkartılmıştır.

Makalede öncelikli olarak Gök-Börü’nün oluşumu, yazarları, ideolojisi ve kapanması incelenmiştir. Araştırma yapılırken başta derginin tüm sayıları, Reha Oğuz Türkkan'ın “Arayan Adam” başılılı hatıraları, sonra II. Dünya Savaşı sırasında çıkan Türkçü yayınları tüm yönleri ile inceleyen kitaplar ve makalelerden yararlanılmıştır. II. Dünya Savaşı yıllarında Türkçü yayınlar konusunda; M. Jacob Landau'nun "Pantürkizm”, Nizam Önen'in “ịi Turan”, Günay Göksu Özdoğan'ın “Turandan Bokurt'a” ve Deniz Güner'in "Savaş ve İktidar" başlıklı kitapları ile Bekir Koçlar'ın "Türk Milliyetçiliği Düşüncesini Tanımlama ve Temellendirme Çalışmalarına Bir Örnek: Ergenekon Dergisi” başlıklı makalesi başvurulan kaynaklar arasında yer almaktadır.

Makalenin yazılmasındaki amaç Türkiye Cumhuriyeti’nin kuruluşu ile birlikte tanımlama güçlüğü çekilen düşünce biçimlerinin başında milliyetçiliğin geldiğini göstermektir. Kuruluş döneminin zorlukları devletin kültürel ve siyasi hayatı denetimi altına almasını gerektirdiğinde Türk Ocaklanı kapatılmıştır. Bunun sonucunda II. Meşrutiyet ile iktidar olan Türkçülük düşüncesi, devletin kurucu ideolojisi olma özelliğini yitirmiş ve muhalefete düşmüştür. Mustafa Kemal'in ölümü ve II. Dünya Savaşı'nın ortaya çıkardığı şartlarda Türkçüler, milliyetçiliğin 
kendi felsefelerine uygun olarak tanımlanması için yoğun bir çaba içerisine girmişlerdir. Ancak değişen dünya şartları onların bu çabasıı kesintiye uğratmıştır. 3 Mayıs 1944 Milliyetçilik Olayları sırasında devletin şiddet yüzü ile karşı karşıya gelmeleri Türkçülerin sonraki hayatlarını şekillendirmiş ve Türkkan yaklaşık otuz yll süreyle Türkiye'yi terk etmiş̧ir. Soğuk Savaş döneminde dünya; $\mathrm{ABD}$ ve SSCB ekseninde bloklaştığında ise Türkçüler bu kez milliyetçiliği antikomünizm temelli tanımlamaya çalısmışlardır.

\section{Gök-Börü'nün Mizanpajı}

Gök-Börü (Bozkurt) dergisi Reha Oğuz Türkkan tarafindan II. Dünya Savaşı ylllarında (5 Kasım 194223 Mayıs 1943) rrkçı milliyetçiliği Türk devlet ve toplum hayatında temellendirme amacıyla 15 günde bir, toplam 13 sayı olarak İstanbul'da çkkartılmıştır. (Türkkan, 2011, s. 93-104).

Derginin kapağı hemen hemen bütün sayllarında aynı formatta çıkmıştr. Buna göre kapağın üst kısmında büyük harflerle "HER IRKIN ÜSTÜNDE TÜRK IRKI" onun altında derginin adı ve üstteki yazıya göre daha büyük puntolu kırmızı zemin üzerinde "GÖK-BÖRÜ" yazısı bulunmaktadır. Kapağın orta kısmında yine kurmızı zemin üzerine bir bozkurt başı ve ay yıldız resmi, solunda GÖK-BÖRÜ (BOZKURT), sağında "Türklüğün Kurtuluşu” altında ise "Birlik ve Zafer Remzidir!" ifadeleri vardır. Onun hemen altında Bozkurt'u takip eden atlı süvari birliği resmedilmiş bunun altında da içindekiler bölümü, onun solunda sayının çıkış tarihi, sağında ise sayı numarası ve son olarak kapağın altında çıkartan R. Oğuz TÜRKKAN ibaresi yer almaktadır.

Genel olarak derginin iç sayfa düzeni 1. sayfa, üstte ortada büyük harflerle GÖK-BÖRÜ yazıII, altında küçük puntolarla "Türkçü Dergi şimdilik 15 günde bir çıkar." ibaresi bu ibarenin sağında adres, solunda abone şartlarıı gösteren bilgilerden oluşmaktadır. Buradaki bilgilere göre derginin abone şartları: Türkiye için 24 sayı, 450 kuruş; 12 sayı, 225 kuruş; 6 sayı, 115 kuruş iken yurt dışı için birer misli olduğu belirtilmiş̧iir. Yine bu bilgilere göre derginin adresi "Türbedar Sokak No: 18 Cağaloğlu/Istanbul" iken basıldığı yer Cumhuriyet Matbaası olduğu belirtilmektedir. Bu bilgilerin altında ise derginin sahibi ve yazı işleri R. Oğuz Türkkan ismi yer almaktadır.

Temel özelliği "Birleşik Bir Türklük" ve "Irkçı Milliyetçilik" algısı oluşturmak olan derginin kimi sayıları özel sayı olarak hazırlanmıştır. Örneğin derginin 5. ve 6. sayları "Gençlik Davası!" başlı̆ı altında çıkarken, gerek Türkkan ve gerekse diğer yazarlar Milli Eğitim Bakanlığını toplayacağı "Gençlik Şurası” na etki etme amacı taşımışlardır. Derginin son sayısı olma özelliği taşıyan 13. sayısı ise, "Azerbaycan” özel sayısı olarak çıkmıştr. Diğer taraftan dergi genel olarak 24 sayfa halinde çıkarken, sadece 9. sayı 32 sayfa çıkmış ayrıca 12. sayıda 16 sayfa, 13. sayıda ise 8 sayfalık, Reha Oğuz Türkkan'a ait "Irka Dair Münakaşalar" başlıklı ilave, dergi içerisinde verilmiştir.

Derginin arka kapağı ağırlıklı olarak "Reklam", "Okuyucularla Baş Başa”, "Türkçülerin Okuyacakları Kitaplar” dan oluşmuştur. Derginin arka kapağında görülen reklamlar, İnhisar Likörleri, Koç Ticaret Türk A.Ş., Tuna Dersevi ve Zeki Subaş'a aittir. Ayrıca Türkçülerin okuması tavsiye edilen süreli yayınlar; Amca Bey, Bucak, Doğu, Millet ve Türk Yurdu mecmuaları olurken kitaplar ise başta Reha Oğuz Türkkan olmak üzere Ahmet 
Caferoğlu, Ahmet Hikmet Müftüoğlu, Cemal Bardakçı, Hüseyin Namık Orkun, Mahmut Hakkı Akansel, Orhan Conker, Ömer Seyfettin, Ziya Gökalp, Zeki Velidi Togan isimlerinden oluşmaktaydı. Arka kapağın en alt kısmında ise Cumhuriyet Matbaası ve 20 kuruş ifadelerine yer verilmiştir.

Dergide yer alan konu başlıkları; Eğitim Davası, Gençlik Davası, Irkçılı, Türkçülük, Türk İktisadi Hayatı, Türk Köylüsünün Sorunlan, Türk Ziraat Davası, Türk Edebiyat,, Türk Folkloru, Türk Musikisi, Türk Tarihi ve Türk Dünyası Hakkında Haberlerden oluşmuştur. Derginin yazar kadrosu ise ağırlıklı olarak; Reha Oğuz Türkkan, Abdülkadir İnan, Aydın Yalçın, Besim Atalay, Halit Bayrı, Mahmut Esat Bozkurt, Mahmut Ragıp Kösemihal, Osman Turan, Reşat Nuri Güntekin, Süreyya Aygün, Şakir Raşit Hatipoğlu, Zeki Velidi Togan, Ziyaeddin Fahri Fındıkoğlu isimlerinden oluşmuştur.

Derginin sahibi ve yazı işleri müdürü durumunda bulunan Reha Oğuz Türkkan ilk sayı dışında derginin başyazılarını kaleme alırken yazılarında kendi ismi dışında "Arayan Adam, Gök-Börü ve Reha Kurtuluş" müstear isimlerini kullanmıştır. Diğer taraftan dergideki şiirler ve karikatürler de okuyucu tarafindan ilgiyle takip edilmiştir. Dergide yer alan şïrler ağırlıklı olarak Cemal Oğuz Öcal ve Elmas Yıldırım imzasını taşırken henüz yirmili yaşlarında olan Bülent Ecevit'in şiirleri de dergide yer almıştır. Okuyucunun ilgiyle takip ettiği karikatürler ise Cemal Nadir, Muammer ve Sadettin Topuzoğlu tarafindan çizilirken derginin kapak kompozisyonları da Cemal Nadir, Nuri Saran ve Sadettin Topuzoğlu üçlüsü tarafindan hazırlanmıştır.

Liseyi yeni bitimiş ve yirmili yaşlarının başında bulunan bir grup genç tarafindan ülkede "Birleşik Bir Türklük” ve "Irka Dayalı Milliyetçilik”" algısı oluşturmak amacıyla çıkartılan dergide (Landau, 1999, s. 134-135) dönemin milliyetçi entelektüelleri olan Abdülkadir İnan, Osman Turan, Ziyaeddin Fahri Fındıkoğlu ve Zeki Velidi Togan'ın yanı sıra Atatürk döneminin önemli isimlerinden Mahmut Esat Bozkurt ve halihazırdaki hükümette Ziraat Vekili olan Şakir Raşit Hatipoğlu'na ek olarak II. Dünya Savaşı sonrası çok partili hayata geçme karanı verildiğinde Milli Kalkınma Partisi (MKP) liderliğini üstlenen Nuri Demirağ'a ayrıca Türkiye'nin sosyalist tarihinde unutulan isimlerden Reşat Nuri Güntekin'e ve son olarak İsmet İnönü sonrası Cumhuriyet Halk Partisi (CHP)'nin liderliğini üstlenecek olan Bülent Ecevit'e derginin sayfalarında yer verilmesi dergiyi özellikli kılan yanı olmuştur.

Dergi yayın hayatı boyunca maddi yetersizliklerle, sonlara doğru da kağıt sağlama teminiyle mücadele etmek zorunda kalmıştır. Bu yüzden kimi sayıları 15 günü aşan sürelerde okuyucuya ulaşmışır. Nitekim derginin 23 Mayıs 1943 tarihini taşıyan son sayısında gelecek sayının 15 Haziran'da çıkacağı ayrıca kağıt sağlama güçlüğünün devam etmesi halinde sonraki sayıların her ayın 1 ve 15'leri olacak şekilde okuyucuya ulaştırılacağı ifade edilmiştir. Buna rağmen dergi 13. sayı ile birlikte İstanbul Örf İdare Komutanlığı'nın emri sonucu süresiz olarak kapatılmış ve dönemde bir daha yayın hayatına dönememiştir (Güner, 2015, s. 186).

\section{Gök-Börü'nün Adı ve Çıkarılış Amacı}

Derginin çıkış amacı Türk devlet ve toplum hayatında ırkçıllğa dayalı bir milliyetçilik algısı

oluşturmaktır. Bilindiği gibi çok uluslu Osmanlı Devleti’nin yıkıntılan üzerinde şekillenen Türkiye Cumhuriyeti'nin ilk yllarında milliyetçilik, tanımlama sorunu yaşayan düşünce biçimlerinin başında gelmiştir. 
Nitekim bu durum yllar içerisinde milliyetçilikle ilgili birçok farkh fikri yaklaşım ve uygulama biçimi ortaya çıkarmıştır (Yıldız, 2001, s. 165-171). Her ne kadar Mustafa Kemal Atatürk liderliğinde kurulan Türkiye Cumhuriyeti'nin kurucu ideali milliyetçilik olsa da Pantürkizm süreç içerisinde reddedilmiş, bu ise Türkçü düşüncenin ve Türkçü kadroların muhalefete düşmesi sonucunu doğurmuştur. Aslında bu sonuç kurucu irade açısından iki noktadan kaynaklanmıştr. Bunlardan ilki Misak-1 Milli ile belirlenen sınılların güvenliğini sağlama ve söz konusu sınırlar içerisinde yaşayan Türk vatandaşlarının hayat kalitesini yükseltme iken ikincisi Serbest Cumhuriyet Frrka (SCF) denemesinde Türk Ocakları çevresinin devletin kurucu ve dönüștiürücü partisi olan Cumhuriyet Halk Furkası (CHF)'na karşı muhalefet denemesini sahiplenmesidir. Sonuçta Türk Ocakları ve Türk Yurdu dergisinin kapatılmasıyla Türkçü kadrolar II. Dünya Savaşı’nın başına kadar sessizliğe gömülmüşșïr.

Diğer taraftan Türkiye Cumhuriyeti'nin kurucu lideri Mustafa Kemal Atatürk'ün 10 Kasım 1938 tarihinde vefatı ve kısa süre sonra II. Dünya Savaşı’nın başlaması yıllardır muhalefete düşmüş Türkçü kadrolar için yeni bir dönemin habercisi olmuştur. Nitekim İnönü/ Milli Şef dönemi diye anılan 1938-1950 yllları içerisinde 1939-1944 arası literatürde kimi araştırmacilar tarafindan Türkçü düşünce ve yayıncılık açısından altın dönem (Özdoğan, 2015, s. 229) olarak ifade edilmiștir. Bu dönemde örneğin; Reha Oğuz Türkkan, Ergenekon, Bozkurt ve Gök-Börü dergilerini; Hüseyin Nihal Atsız, Orhun dergisini; Rıza Nur, Tanrıdağ dergisini yayınlarken Edirne, Gaziantep, Samsun ve Zonguldak gibi taşra merkezlerinde de Türkçü yayınların çıktığı görülüyordu (Önen, 2005, s. 280-281). Aslında Milli Şef İnönü açısından bu süreçte en sorunlu ideolojik çevre Türkçüler idi. Zira onlar devletin kendisini Misak-1 Milli sınırları ile sınırlandırmasına karşı çıkıyorlardı. Bu nedenle içinde bulunulan şartlarda onların göz önünde tutulmasını zorunlu kiliyordu. Nitekim dönemin sonunda yaşanacak 3 Mayıs 1944 Milliyetçilik Olaylan, mahkemeler ve tabutluk süreci başta Atsız ve Türkkan olmak üzere önemli sayıda Türkçü ismi mağdur edecek gelişmelerin yaşanmasına sebep olmuştur.

Derginin 5 Kasım 1942 tarihini taşıyan ilk sayısında Gök-Börü (Bozkurt)'nün kaynağı Türk destanlarnnı başlıca kahramanı ve Türk neslinin atası olarak gösterilmiștir. Buna göre; dünkü ve bugünkü bütün Türkçülerin milli remzi olan Gök-Börü'nün en önemli işlevi Türkler arasında siyasi, sosyal, ekonomik ve kültürel olarak birleştirici bir görev görmesiydi (Gök-Börü, 1942, s. 2-23). Buradan hareketle Türkiye Türklügünün Mustafa Kemal Atatürk ile girdiği millilik yolundan onun ölümüyle çıkacağı endişesini taşıyan Türkkan ve çevresinin Gök-Börü dergisini gündem oluşturmak amacıyla çıardığmı söylemek mümkündür.

Gök-Börü’nün ilk sayısında çıkış amacı en temiz ve en koyu haliyle milliyetçilik olarak dile getirilmiştir. Ayrıca birleşik, hür, kalkınmış, zengin bir Türk yarıı kurmak için derginin Türk hayatının her alanını tehdit eden zihniyetlerle mücadele edeceği bunlara ek olarak Türklüğün kültür, medeniyet ve tarihine ilişkin ciddi araştırmalar içereceği ifade edilmiştir (Gök-Börü, 1942, s. 2). Bununla birlikte Türkçüler arasındaki fikri ayrllkların ve liderlik çekişmesinin de derginin çıkmasında önemli bir sebep olduğu görülmektedir. Bu noktada "Hesap Veriyoruz" başııkı yazısında Cihat Savaş Fer bu durumun ip uçlarını dile getirmektedir. Yazısında Fer, Atsı'’n davasında samimi fakat şeflik hülyasına sapl, iradesi zayıf ve hislerine mağlup bir insan olmasından dolayı onunla yollarııı ayırdıklarıı söylemiştir. Buna ek olarak Çınaraltıcıların ise, Bozkurt'un yayınlanmaması 
için hükümet nezdinde yaptıkları çalışmalardan haberleri olduktan sonra kendileriyle ilgilerini kestiklerini ve gerçek Bozkurtçular olarak Gök-Börü’ yü çıkarttıklarını ifade etmiştir (Fer, 1942, s. 3).

Gök-Börü’nün bütününe bakıldığında öne çıkan birkaç temel özelliğinin olduğu göze çarpmaktadır. Bu özelliklerin birincisi, Türk inkılabını "Ṫhtilal değil şuurlu ve tekamüle gidici bir milli hamle” (Buharal, 1943, s.10) olarak görürken ikincisi, "Her ırkın üstünde Türk ırkı!” söylemine karşı kimi çevrelerce geliştirilen Alman taklitçisi olma yönündeki eleştiriye karşı çıkması olmuştur. Bu noktada en ilginç çıkışlardan biri Atatürk’ün ölümüyle siyasal alanda muhalefete düşen Mahmut Esat Bozkurt tarafindan dile getirilmiştir. Bozkurt "Milliyetçilerin Cevabı" başlı̆̆ını taşıyan yazısında kendilerinin "dil ve kültür bakımından dünyanın en yüksek milleti olma idealini taşıdıklarını" ayrıca ırkların eşit olmadığına, yüksek ırkların var olduğuna inandıklarını söylemiş ve "Türklerin eserleriyle, karakterleriyle, tarihleriyle hiçbir milletin boy ölçüşemeyeceğini”" (Bozkurt, 1943, s. 12-14) ifade etmiştir.

Derginin yayınlandığı dönemde öne çıkan üçüncü özelliği, öteki olarak görülen çevrelere karşı meydan okuyucu bir üsluba sahip olmasıdır. Bu meydan okuyucu ya da kavgacı hali başta Türkkan olmak üzere derginin bütün yazarlarında görmek mümkündür. Bu noktada örneğin; "Solcu Sapıklara Bozkurt Cevabı!” başlıklı yazısında Bozkurt "Biz Türklerin işlerine, her ne sebeple ve her ne mevzuda olursa olsun sizin gibi yabancı kanlı, yabancı kafalı ve yabancı ruhlu çalışanların karışmaya hakkı yoktur!” (Bozkurt, 1943, s. 2) derken Türkkan ise II. Dünya Savaşı'nın doğurduğu ekonomik zorluklarla mücadele etmek için hükümetin 11 Kasım 1942 tarihinde TBMM'de kabul ettiği ve büyük oranda ülkede yaşayan gayrimüslim azınlığı kapsayan Varlık Vergisini "eşine mali tarihimizde rastlanmamış büyük bir İnkılap" olarak nitelemiş ayrıca verginin muhatabı olan azınlıklara "bazı maddi hatalar yapılsa, servetlerinden eser kalmasa bile hükümetin adil kararının onları, Türk halkının kininden ve felaketten koruduğunu" söyleyerek uygulamadan duyduğu memnuniyeti belirtmiştir (Kurtuluş, 1934, s. 11).

Geniş halk kitlelerine dönük bir dil kullanma ve bunun sonucunda kitleleri başta tarih olmak üzere budunbilim, edebiyat, din, felsefe, iktisat ve sosyoloji konularında bilinçlendirerek aydın çevresinin bir parçası haline getirme derginin yayınlandığı dönemde öne çıkan dördüncü özelliği olurken, beşinci özeliği ise, Türk milletinin maddi ve manevi hayatını tahrip ettiği düşünülen davranış bozukluklarına karşı gelmesi olmuştur. Bu noktada dergide yer alan yazı, şïr ve karikatürlerde Türk köylerinde gençler arasında alkol tüketiminin artması ve kumar alışkanlığının yaygınlaşması, şehirlerde Amerikan, İngiliz yaşam tarzını gösteren öğelerin görülme sıklı̆ııın artması vb. gelişmelerden duyulan rahatsılılk dile getirilmiştir (Hatipoğlu, 1943, s. 13-14). Bunlara ek olarak derginin yayınlandığı dönemde ortaya çıkan son özelliği militarizm/ savaş yanlısı olma (Akgün, 1942, s. 12) ve buna bağhı olarak da antikomünizm (Türkkan, 1943, s. 3) olmuştur.

\section{Gök-Börü'nün Türkçülük Anlayışı}

Öncüleri olan Ergenekon ve Bozkurt gibi Gök-Börü de Türkçü çizgide bir yayımdır. Nitekim bu durum derginin ilk sayısında okuyuculara açıkça haber verilmektedir: 'Gök-Börü, Türkçülüğün mecmuasıdır. Öz Türkler tarafindan çıkartılan ve gene Öz Türklerin olan bu dergi, en temiz ve en koyu manasiyla milliyetçidir. Onun için, neşriyatında tek ruh, budur. Bu ruhun, mecmuanın sahifelerinde tezahür ve telkin şekilleri şüphesiz ki 
yeknesak olmayacaktrr. Ana ülkü davaların ele alacak kuvvetli başmakale ve makalelerle birlikte, Türklügün tarih, kültür ve medeniyetine dair ciddi tetkikler, memleket davalarının teşrih ve tenkidi, sakat zihniyetlerle mücadele, şiirler ve tezli romanlar, hep bu hedef için çalışan silahlar olacaktır." (Gök-Börü, 1942, s. 2). Bu kısa tanııım yazısında görüleceği gibi derginin içeriğinin ülkede rrkçlığa dayalı bir milliyetçilik algısı oluşturma doğrultusunda kullanılacak bir silah olduğu belirtilmektedir.

TBMM kürsüsünden Başbakan Şükrü Saraçoğlu’nun 'Biz Türk’üz, Türkçüyüz ve daima Türkçü kalacağız. Bizim için Türkçülük bir kan meselesi olduğu kadar ve en az onun kadar bir vicdan ve kültür meselesidir. Biz azalan ve azaltan Türkçü değil çoğalan ve çoğaltan Türkçüyüz ve her vakit bu istikamette çalısacağı!!' (Hür, 2015, s. 87-88) sözlerini haykırdığı bir süreçte "Her Irkın Üstünde Türk Irkı!” logosu ile çıkan Gök-Börü dergisinin en temel özelliği rrkçllığa dayalı bir milliyetçilik anlayışına sahip olmasıdır.

Başta Türkkan olmak üzere dergi yazarlarnnın tümü tarafindan "rrk" inkârn mümkün olmayan bir gerçeklik olarak kabul edilmiş ve Türk tarihi üzerinden bir üstün ırk teorisi oluşturulmaya çalışılmıştır. Yazarların ortak kanısı Türklerin tarihinin farklı dönemlerinde yeryüzünün farklı mekanlarında üstün bir kültür ve medeniyet hayatı meydana getirdiği, ancak yabancılarla evlenme, dillerini korumada özen göstermeme, üst düzey devlet görevlerinde yabancı kanından olanlara yer verme vb. nedenlerle sonuçta inkıraza uğradığı anlatılmaktadır. $\mathrm{Bu}$ hatalardan ders çıkarılmasını isteyen Zarakol, "Bugün ırsiyet inkârı kabul olmayan, müspet ilmi bir hakikattir. Biz de ibret alacak bir kafa varsa, eğer yüzlerce defa tekerrür etmiş bir hatayı tekrarlamak istemiyorsak tutulacak bir yol vardır: ırkçılık" (Zarakol, 1943, s.6) şeklinde yapılması gerekli olanı belirtirken, Türkkan da milliyetçilik şuurunun Türklerde tarihin eski zamanlarından itibaren olmasına rağmen milliyetçilik şuurunun zayıflığının tarihin her döneminde felaketlerin yaşanmasına sebep olan ikilem olarak göstermiştir. Milli Şef İnönü döneminde eğitim ve kültür alanlarnnda hümanizma şeklinde ortaya konulan uygulamaları Atatürk dönemindeki millilik anlayışından uzaklaşma olarak gösteren Türkkan, söz konusu dönemde Gökalp'in "Garplılaşmak" söyleminin batı medeniyetinin kopyalanması şeklinde yanlış anlaşıldığını söyleyerek halkın Türklüğe bağıllığının hem fiziki (adlar, başlık ve giyiniş, ev düzenlemesi ve mimarisi vb.) hem de ruhen (basın, edebiyat, okul, sinema ve tiyatronun Türklük duygusunu aşlaması, dinin Türkleştirilmesi vb.) sağlanması için "Milli İnkılap" başı̆̆ı̆ı taşıyan bir proje önermiş̧ir (Türkkan, 1943, s. 3-7).

"Her Irkın Üstünde Türk Irkı" logosu ile çıkan dergi dönemde kimi çevrelerce bu sloganın Almanların ünlü "Deutschland Über Alles" (Her şeyin Üstünde Almanya) sözünden ilham alarak oluşturulduğu ve rrk kavramının da ilmi olmaktan ziyade günün popülerliğine uygun bir anlayış olmakla eleştirilmiştir. Bu eleștirilere karşı başta Türkkan olmak üzere Gök-Börü’nün yazarları söz konusu çevreleri "Mason, Solcu ve Yahudi" şeklinde nitelemelerle ötekileşirme yolunu izlemişler ayrıca bu söylemin ve ırkçılık anlayışlarının Almanlardan esinlenerek değil, Türk tarihinden ilham aldığını (Bozkurt, 1943, s. 22-23) söylemiş̧lerdir. Türkkan da "Lafta (üstün ırkzz!) demek kolay. Bakı, hakikatte Avrupalılar ve Amerikalılar bizden daha üstün..." şeklinde kendilerini eleştirenleri "üstün ırk" ve "ileri millet” tabirleri arasındaki farkı bilmemekle itham etmiştir. Buna göre; “üstün ırk” doğuştan gelen savaşçılık, medeni kabiliyet, teşkilatçllk vb. özelliklerin nesilden nesil'e kan bağı ile 
aktarılması iken, "İleri Millet” ise kültür, medeniyet, teknik, siyaset vb. alanlarda ileri seviyeye ulaşmış olan toplumları ifade etmektedir. MÖ 5000 - MS 1700 yllarına kadar hem 'Üstün Irk" hem de "İleri Millet" olmayı başaran Türkler tarihin sonraki dönemlerinde milliyet taassubunun kaybedilmesi ile "Ileri Millet'ler safindan silinmiştir. Buradan hareketle bugün batılı toplumlar her ne kadar Türkiye'den çeşitli yönlerden ileri seviyede olsalar da ırk olarak üstün olanın Türkler olduğunu vurgulayan Türkkan, "En üstün ırktan olan Türk soyunun tekrar en ileri millet olması mukadderdir. Biz buna inanıyoruz, buna çalışıyoruz. İnanmayanlar ve çalışmayanlar bizden değildir.” (Türkkan, 1943, s. 3-4) şeklinde düşüncesini ifade etmişsir.

$\mathrm{Bu}$ arada Gök-Börü'deki ilginç bir ırkçlık yorumu da, Kızılbaşlık üzerine kaleme alınan bir yazıda kendini göstermiştir. Zarakol, “Kızılbaşlık” başlığı ile kaleme aldığı yazısında geleneklerini, kanlarını, kültürlerini koruma noktasında gösterdikleri özenden dolayı Kızılbaşığı yabancı ülkelere giren Türk kitlelerinin sağdan soldan gelen tesirlere karşı bir direnci, bir benliği koruma hareketi (Zarakol, 1943, s. 6) olarak göstermiştir.

Diğer taraftan Gök-Börü’nün Türkçülüğünün bir boyutu ırka dayalı milliyetçilik algısı oluşturmak iken, diğer boyutu da Sovyet Rusya hakimiyetindeki Türk Dünyasına dönük Türkiye Türkleri arasında ilgi oluşturmaktır. $\mathrm{Bu}$ amaç doğrultusunda başta Türkkan olmak üzere derginin yazarları Sovyet Rusya hakimiyetindeki Türk dünyasını coğrafya, dil, din, folklor, nüfus, tarih vb. özellikleriyle Türkiye Türklerine tanıtmak için gayret göstermişlerdir. Bu noktada ömeğin özel bir sayı ile Azerbaycan'ın çeşitli yönleriyle ele alındığı ve okuyucuya tanıtıldığı (Türkkan, 1943, s. 3; Kurat, 1943, s. 9-10; Altunbay, 1943, s. 10-11; İnan, 1943, s. 17-19) görülmektedir. Buna ek olarak musiki (Kösemihal, 1942, s. 9-10), düğünler (Bayn, 1942, s. 16; İnan, 1942, s.17-18), spor oyunları (Ülkütaşır, 1943, s. 7-8) üzerinden Türkiye'de Türk Dünyasına dönük ilginin artırılmaya çalışıldığını söylemek mümkündür.

Bununla birlikte Türkkan, dergide Türkçülük anlayışının sanılanın aksine sadece Türk Birliği üzerine kurulu olmadığını ve Anadolu'nun sorunlanı çözülmeden Türk Birliği’nin sağlanamayacağını öngördüklerini dile getirmiştir. Nitekim Türkkan'a göre, Türk Dünyası'nın birliğine liderlik edecek olan Türkiye'nin ilk başta Irk/ milliyet olmak üzere ahlâk, aile ve kadın, dil, din, eğitim ve gençlik, ilim ve fen, idare, istihdam, nüfus ve sanayileşme konularını çözerek güçlenmesi (Türkkan, 1942, s. 5-6) gerekmektedir. Türkkan'ın bu yaklaşımı derginin yazarları tarafindan paylaşılmıştır. Bu noktada örneğin edebiyata (Güntekin, 1942, s. 13-14), ilime (Yalçın, 1942, s. 12), ormana ve ziraata (Hatipoğlu, 1942, s. 10-11) dönük Anadolu'nun sorunlarını içeren yazıları dergide görmek mümkündür.

\section{Gök-Börü'nün Eğitim ve Gençlik Konularına Bakışı}

Gök-Börü’nün yazarları Türklük duygusunun ve Türkçülügü̈n en parlak zaferi olarak niteledikleri Türkiye Cumhuriyeti'nin ilelebet yaşayabilmesi için eğitim ve gençlik konularına dikkat edilmesini (Türkkan, 1943, s. 3-4) istemişler ayrıca bu hedefin ortaya çıkması noktasında eğitimi ve onun bir unsuru olan öğretmeni araç olarak görmüşlerdir. Bu noktada örneğin öğretmenlerin, vatan müdafaasında en büyük rolü oynayan gençliğin maneviyatının şekillendirilmesinde aileden daha fazla etkili olduğu söyleyen Tesbihçioğlu, ögretmenlerin Türk milliyetçiliği ve vatan fikirlerine meyilli olması ve öğrencilerini bu yönde yetiştirmeleri 
gerektiği; aksi takdirde bu yoldan zerre kadar şaşan öğretmenin kafasına milli öfke yumruğunun ineceği (Tesbihçioğlu, 1943, s. 19) uyarısında bulunmuştur. Türkkan da doğuşundaki suçun topluma ait olduğunu söylediği “Yeni Genç”e karşı eğitimi ve öğretmeni ideal Türk gencini ortaya çlkartmakla sorumlu tutmuştur. "Yarının Genci” başlıklı yazısında Türkkan ideal Türk gencini manevi ve fiziksel olarak tasvir etmiş̧i. Buna göre Türkkan'ın ideal Türk gencinin manevi bileșenleri, “Türk milliyetçisi, ahlakll, çalışkan, dürüst, fen ve ilimde önde olma; hırsılık, iltimas, solculuk, sapıklık ve beynelmilelcilikten uzak olma" özelliklerini gösterirken, fiziksel bileşenleri ise "iri yapıll, geniş omuzlu, kanlı canlı, dinç ve gürbüz olma" (Türkkan, 1943, s. 3-4) özelliklerini taşımıştr. Burada Türkkan'ın tasvir ettiği ideal Türk gencinin fiziksel boyutunun tarihteki Türk kahramanlıklarını ve zaferlerini yeniden yaratma amacı taşımakla birlikte devam etmekte olan II. Dünya Savaşı'na her an girme ihtimaline karşı ülkenin savaşacak insan unsurunu fiziksel ve psikolojik olarak hazırlama amacı taşıı̆ı̆ını söylemek mümkündür.

Diğer taraftan Gök-Börü’nün 5. ve 6. sayıları özel sayı şeklinde “Gençlik Davası!” başlı̆̆ıla çıkmıştı. Derginin 6. sayısında bu durumun sebebi yakında toplanacak Milli Eğitim Şurası'nın bu konuya dikkatini çekme olarak gösterilmiş̧ir. Gençlik davasını geçmişi ve geleceği ile bütün Türk gençliğinin davası (Kurt, 1943, s. 18-19) olarak gören dergi gençliğin iyi yetiştirilmesi yolunda eğitimi "zihniyet ve milliyet inkılabını" gerçekleştirecek araç olarak görmüş ve bu noktada "millici bir terbiye sistemi”" nin kurulmasını (Buharalı, 1943, s. 12-20) istemiştir. Bugün artk maddi ve manevi her faaliyet milli olmak zorundadır diyen Gök-Börü’ye göre kurulacak olan "millici terbiye sistemi”" gençleri vazifeşinas kılmalı (Akgün, 1942, s. 6; Bozkurt, 1942, s. 20), intizamsızlık hastalığından kurtarmalı (Bozkurt, 1942, s. 20), geleneksizlik ve taklitçilik zihniyetinden uzak olmalı (Zarakol, 1943, s. 4-5), dil, tarih, musiki, mimari ve gündelik hayat alanında yaşanan yozlaşmadan uzak durmalı (Türkkan, 1942, s. 3-4) idi.

Gök-Börü’nün 5., 6., 7. ve 8. saylarında “Yabancı Ülkelerde Terbiye Sistemleri ve Gençlik” başlğıyla kaleme aldığı seri yazılarında Türkkan, İngiliz eğitim-öğretim ve terbiye sistemlerini inceleyerek bunlardan Türkiye'ye dönük sonuçlar çıkarmaya çalışıştır. İngiliz eğitim sisteminin en bariz yönünün İngiliz Irkının hususiyetlerini (hür ve müteşebbis, bilgili, pratik, gürbüz ve sporcu vücutlu) geliştirmeyi amaçladığını (Türkkan, 1943, s. 9-10) söyleyen Türkkan, sınıfta "gerçek öğrenmenin" oluşması için öğretmenin monolog halinde değil diyalog halinde ders işlemesinin önemsendiğini (Türkkan, 1943, s. 11-20), okulların büyük, çıllak ve soğuk görünümlü yapılar olmayıp, hakiki bir hayat manzarası taşılığını ve şehrin dışında kırlarda kurulduklarını (Türkkan, 1943, s. 9-10), eğitimde önceliği pratiğe vererek öğrenmeyi tecrübe ile kazandırma dolayısılla soyut olan her bilgiye somut olanla ulaşma yolunu izlediklerini aynca dil eğitiminde ezbercilikten uzak tümevarmm yöntemini başaryyla uyguladıklarını ( Türkkan, 1943, s. 9-11) söyleyerek bu unsurların Türk eğitim sisteminde de hayata geçirilmesini istemiştir. Burada ilginç olan nokta hemen her yazısında kültürel yozlaşmaya ve gençliğin başka milletlere öykünmesine karşı çıkan Türkkan'ın, İngiliz eğitim-öğretim ve terbiye metotlarıı Türk eğitim sistemine bir örnek olarak göstermiş olmasidır.

Sofuoğlu da "Kökten Bir Değişiklik Lazım!” başlıkı yazısında milliyet ve fikir yönünden heyecanı 
olan, dinamik, disiplinli ve karakterli bir gençlik yetiştirmeyip toplumu amaçsız, hayalci ve tembel bir nesille karşı karşıya bırakmakla suçladığı eğitim sisteminin terk edilmesini ve yerine "idealizm, milliyet, romantizm ve ülkü aşkına ağırlı veren” (Sofuoğlu, 1943, s. 7-9) eğitim sisteminin uygulamaya konulmasını istemiştir. Aynı şekilde Türkiye'de sivil havacılık kurma çabasının önde gelen ismi Nuri Demirağ da pilot yetiştirmek amacıyla açtığı Gök Okuluna devam eden genç pilot adaylarından “işretten, oyundan, iffetsizlikten, tembellikten” uzak durmaları (Gök-Bekçisi, 1943, s. 8-10) tavsiyesinde bulunmuştur.

\section{Sonuç}

Gök-Börü Dergisi, II. Dünya Savaşı yıllarında yayımlanmış olan Irkçı, Turancı, Türkçü nitelikteki bir süreli yayımdır. Cumhuriyet değerlerini bu merkezden ele almış özellikle milliyetçiliği bu açıdan yorumlamaya çalışmıştır. Derginin yayımlandığı dönemde öne çıkan altı özelliği vardır. Bunlardan birincisi öncüleri olan Ergenekon ve Bozkurt'taki gibi 'Her Irkın Üstünde Türk Irkı" logosu ile çıkmasıdır. Derginin ikinci özelliği Türklerin kendisine has ve üstün olduğunu anlatmaya çalışması ayrıca Batı emperyalizmine karşı Türk milletini içinde bulunduğu maddi ve manevi çöküş halinden kurtarmanın yolunun rkçılıktan geçtiğini dile getirmesidir. Derginin yayımlandığı süreçte öne çıkan üçüncü özelliği Türkçülüğün temel meselelerine dönük Hüseyin Nihal Atsız ve Reha Oğuz Türkkan arasındaki fikir ayrılıkları ve liderlik çekişmesi sonrasında çıkması ayrıca yazarları arasında Mahmut Esat Bozkurt, Nuri Demirağ ve Bülent Ecevit'in yer almasıdır. Derginin dördüncü özelliği geniş halk kitlelerini aydın çevresinin bir parçası haline getirmek için sade bir dil kullanması ayrıca Türk toplumunun maddi ve manevi hayatını tahrip ettiği düşünülen davranış bozukluklarına karşı çıkması yine militarizmi överken antikomünist bir söylem geliştirmesidir.

Dergiyi çıkaranların, başta Reha Oğuz Türkkan olmak üzere henüz liseyi yeni bitirmiş dokuz genç olması beşinci özelliği olurken, altıncı ve son özelliği ise Alman ırkçılığına karşı Türk ırkçlığı iddiasını taşıması ek olarak Türkiye'nin dış politikada ürkek ve teslimiyetçi politikalarına isyan etmesidir. Türkiye Cumhuriyeti'nin kuruluşundan Mustafa Kemal Atatürk’ün ölümüne kadar geçen süreçte aşama aşama muhalif duruma düşürülen Türkçülük düşüncesi Atatürk’ün ölümü ve II. Dünya Savaşı şartlarında Türkiye’nin fikri ve siyasi hayatına yeniden girmiştir. İște böyle bir atmosferde 13 sayı çıan Gök-Börü dergisi, Türk milliyetçiliği düşüncesini cumhuriyet çizgisinin dışına çıkartarak, daha çok ırka vurgu yapan bir milliyetçilik algısı oluşturması açısından da ciddi bir örnektir.

Diğer taraftan dergide Türkiye'nin gündemini meşgul eden gelişmeler, sosyal, ekonomik ve kültürel meseleler de okuyucuyla paylaşılmıştır. Türkiye'nin ancak Türkçülük düşüncesiyle yükselebileceğine inanan Gök-Börü'de ırkçılık kavramı sürekli işlenmiş ve tartışılmıştır. Misak-1 Milli temelli bakış açısını reddeden dergi Büyük Türk Birliği düşüncesini savunmuş, özellikle Türkiye dışındaki Türklerle Türkiye arasındaki bağların kuvvetlenmesi için çaba sarf etmiştir. Bu noktada kültürel ve tarihi bağlara özellikle vurgu yapılmıştır. Her ne kadar Büyük Türk Birliği düşüncesi Gök-Börü’nün sonunu getiren bir gelişme olmuşsa da dönemde bu fikrin Türkiye Türkleri arasında karşılık bulduğu sonucuna varılmaktadır.

Mustafa Kemal'in ölümü ve II. Dünya Savaşı'nın ortaya çıkardığı şartlarda Türkçüler, milliyetçiliğin 


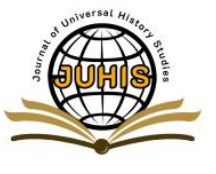

kendi felsefelerine uygun olarak tanımlanması için yoğun bir çaba göstermişlerdir. Ancak değişen dünya şartları onların bu çabasını kesintiye uğratmıştır. 3 Mayıs 1944 Milliyetçilik Olayları sırasında devletin şiddet yüzü ile karşı karşıya gelmeleri sonraki hayatlarını şekillendirmiş ve Türkkan yaklaşık otuz yıl süreyle Türkiye'yi terk etmiştir. Soğuk Savaş döneminde dünya $\mathrm{ABD}$ ve SSCB ekseninde bloklaştığında ise Türkçüler bu kez milliyetçiliği antikomünizm temelli tanımlamaya çalışmışlardır. 


\section{Kaynakça}

[1] Akgün, Nuri(1942), “Savaş ve İnsanlık”, Gök-Börü, sayı 2,(5-6).

[2] --_(1942), “Disiplinin Unsurları”, Gök-Börü, sayı 3, (5-6).

[3] Altunbay, Mehmet(1943), “Azerbaycan”, Gök-Börü, sayı 13, (10).

[4] Bayr, Halit(1942), “Anadolu'da Dügün”, Gök-Börü, sayı 1, (16-17).

[5] Bozkurt, Mahmut Esat(1943), “Milliyetçilerin Cevabı!”, Gök-Börü, sayı 4, (10-12).

[6] Bozkurt, O.(1942), “İntizamsızlık”, Gök-Börü, sayı 2, (20).

[7] --_(1942), “Vazifeşinas Değiliz”, Gök-Börü, sayı 3, (20).

[8] -_-_(1943), “Her Irkın Üstünde Türk Irkı Formülünü Anlamayanlar!”, Gök-Börü, sayı 4, (22-23).

[9] -_(1943), 'Solcu Sapıklara Bozkurt Cevabı!”, Gök-Börü, sayı 5, (2-21).

[10] Buharal, Nebil(1943), “Milli Terbiye”, Gök-Börü, sayı 6, (12-20).

[11] -_(1943), “Bizde Fikir Hayatı”, Gök-Börü, sayı 8, (10).

[12] Fer, Cihat Savaş(1942), "Hesap Veriyoruz”, Gök-Börü, sayl 1,(3-4).

[13] Gök Bekçisi(1943), 'Nuri Demirăg Gök Okulu”, Gök-Börü, sayı 7, (8-10).

[14] GÖK-BÖRÜ(1942), “Ülküdaşlarımıza”, Gök-Börü, sayı 1, (2).

[15] -_(1942), “Gök-Börü Tabiri ve Manaları”, Gök-Börü, sayı 1, (2-23).

[16] Güner, Deniz(2015), Savaş ve İktidar, Yeditepe Yayınevi, İstanbul.

[17] Güntekin, Reşat Nuri(1942), “Kapalı Bahçe”, Gök-Börü, sayı 1,(13).

[18] -_Bahçeli Lokanta”, Gök-Börü, sayı 2, (13).

[19] --_(1942), ‘Büyük Suçlu!’, Gök-Börü, sayı 3, (13).

[20] Hatipoğlu, Şakir Raşit(1942), “Ziraat Davamız”, Gök-Börü, sayı 1, (10-11).

-(1943), “Köylü ve İçki”, Gök-Börü, sayı 4,(13).

[22] Hür, Ayşe(2015), İnönü ve Bayarlı Yillar (1938-1960), Profil Yayınlan, İstanbul.

[23] İnan, Abdülkadir(1942), “Kırgzz-Kazak Düğünleri”, Gök-Börü, say1 2, (18-19).

[24] --_Diş Türklerde Düğün”, Gök-Börü, sayı 3, (17-18).

[25] --_(1943), “Gök-Börü Oyunu”, Gök-Börü, sayı 6, (16).

[26] --_(1943), “Başkurt Düğünü 1”, Gök-Börü, sayı 8, (16). 

-(1943), “Başkurt Düğünü 2”, Gök-Börü, sayı 13, (18).

[29] Koçlar, Bekir(2013), "Türk Milliyetçiliği Düşüncesini Tanımlama ve Temellendirme Çalışmalarına Bir Ömek: Ergenekon Dergisi”, History Studies, say1 5/2, (263-286).

[30] Kösemihal, Ragip(1942), “Türk Musikisi 1”, Gök-Börü, sayı 2, (9-18). (1943) “Türk Musikisi 2”, Gök-Börü, sayı 7, (19-20).

[32] Kurat, Akdes Nimet(1943), “Dış Türklerin İstiklal Mücadeleleri”, Gök-Börü, sayı 9, (9-10).

[33] Kurtuluş, Reha(1943), “Varlık Vergisi!”, Gök-Börü, sayı 5, (11-12).

[34] Kut, Hakkı(1943), “Gençlik Davasının MaarifCephesi”, Gök-Börü, sayı 6, (18-19).

[35] Landau, Jacob M.(1999), Pantürkizm, Sarmal Yayınevi, İstanbul.

[36] Önen, Nizam(2005), İki Turan, İletişim Yayınları, İstanbul.

[37] Özdoğan, Günay Göksu(2015), Turan'dan Bozkurt'a, İletişim Yayınlar, İstanbul.

[38] Sofuoğlu, Zeki(1943), “Kökten Değişiklik Lazım”, Gök-Börü, sayı 5, (7-9).

[39] Tesbihçioğlu(1943), “Öğretmenlere Dair...”, Gök-Börü, sayı 6, (19).

[40] Türkkan, Reha Oğuz(2011), Arayan Adam, Cilt 1, PozitifYayınlar, İstanbul.

[41] --_(2011), Arayan Adam, Cilt 2, Pozitif Yayınları, İstanbul.

[42] --_(1942), "Türkçülüğge Bakışlar”, Gök-Börü, say1 1, (5-6).

[43] --_(1943), “Milliyetsizliğe Doğru!’, Gök-Börü, sayı 3, (3-4).

[44] -_-_(1943), 'Milliyetçiliğe Doğru!', Gök-Börü, sayı 4, (3-7).

[45] -_(1943), “Yabanc Ülkelerde Terbiye Sistemleri ve Gençlik 1”, Gök-Börü, sayı 5, (9$10)$.

[46] -_(1943), “Yarının Genci”, Gök-Börü, sayı 6, (3).

[47] --_-_-_(1943), “Yabanc Ülkelerde Terbiye Sistemleri ve Gençlik 2”, Gök-Börü, sayı 6, (9$10)$.

[48] -_-_(1943), “Yabancı Ülkelerde Terbiye Sistemleri ve Gençlik 3”, Gök-Börü, sayı 7, (1120). -(1943), ‘Yabancı Ülkelerde Terbiye Sistemleri ve Gençlik 4”, Gök-Börü, sayı 8, (1718). 
[50] -_(1943), “'̈leri Millet ve Üstün Irk”, Gök-Börü, sayı 10, (3-4).

[51] - (1943), “Büyük Türklük”, Gök-Börü, sayı 13,(3-4).

[52] Ülkütaşır, Mahmut Şakir(1943), 'Türklerde Oyun ve Sporlar', Gök-Börü, sayı 6, (7-8)

[53] --_(1943), “Gök-Börü Oyununun Anadolu'daki İzleri”, Gök-Börü, sayı 6, (15-16).

[54] Yalçın, Aydın(1942), 'Yüksek Tahsil Davamız ve Eksiklerimiz”, Gök-Börü, sayı 1,(12).

[55] Yıldı, Ahmet(2001), Ne Mutlu Türküm Diyebilene, İletişim Yayınlan, İstanbul.

[56] Zarakol, Tevfik(1943), “Anane”, Gök-Börü, sayı 10, (4-5).

[57] -_-_(1943), “Kızılbaşlar Hakkında Bir Müşahede”, Gök-Börü, sayı 11, (6).

[58] -_(1943), “Türk Tarihinden Irkçılığa”, Gök-Börü, sayı 12,(6). 
ISSN: 2667-4432

Journal of Universal History Studies (JUHIS)・ 2(1)• June• 2019 • pp. 134-153

\section{Ekler}

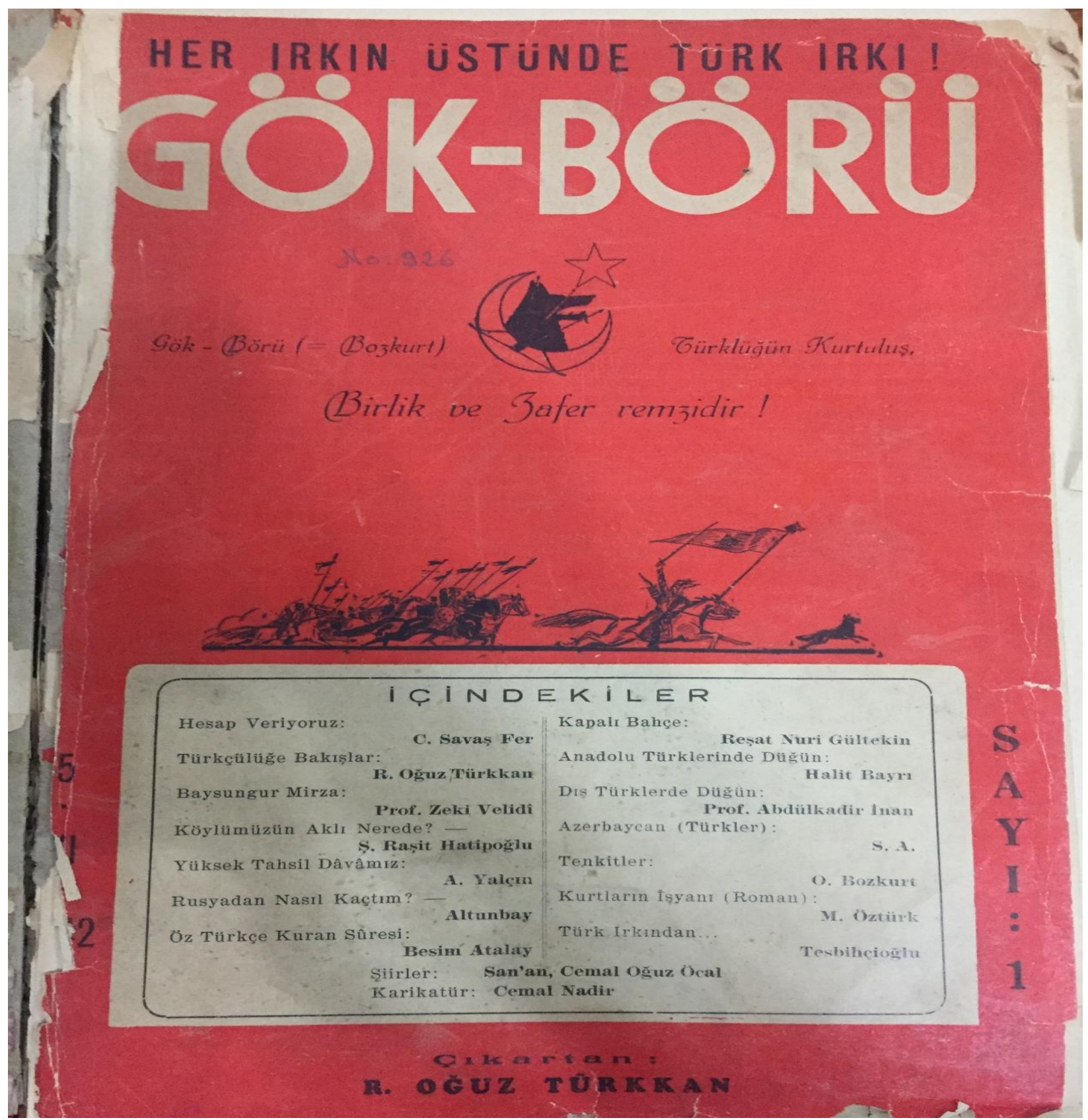

Ek-1: Gök-Börü Dergisi 1. Sayı Kapağl 
Gideceği yer :

\section{DÖRT IÇTIMÂi MESELE R. Oğuz Türkkan}

1. Ahlak (Ahlak buhran karșisında, ideal bir ahlak terbiyesi nasil olmalrdri? )

arletler arasinda müsavat mefhumunun cepheleri)

Haks ne demektir, Haksizc ne3) Hak ve Haksilık (Milletler arası münasebetlerinde Hak ne dem dir?)

4) Milli Menfaat (Cemiyet ve milletler hayatında en büyük hakikat, her turlú safsatalarm arkasında, Millî Menfaattrr) Bozkurt Yaymi - 25 kurus (Idarehanemizden isteyiniz)

Dergiler :

Türk Yurdu, Yurt, çığır, Millet, Doğu, Amcabey dergilerini okuyunuz!

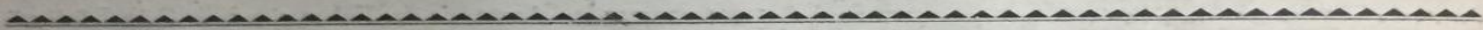

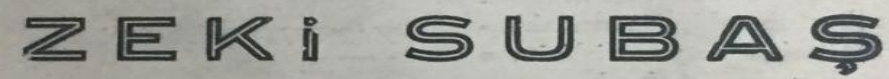

Yeni Valde Hanı Nu. 78

Bilumum Dâhilî Ticaret

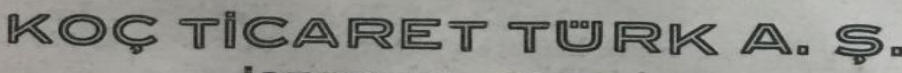
ISTANBUL ȘUBESI

Her nevi boru ve aksami

“ÛNYON, kazan ve radyatōrleri

"JUNKERS \& Co." otomaiları

“ JUNKER \& RUH " gaz ocaklari

GALATA - Fermeneciler No. 90 - ISTANBUL
Banyo ve sibhi tesisat malzemesi

$$
\text { Oksijen - Karpit }
$$

Karo fayans ve karo seramik çesitleri

Levha çinko ve kurşun boru çeşitleri

$$
\text { Teiefon : 44761-44762 }
$$

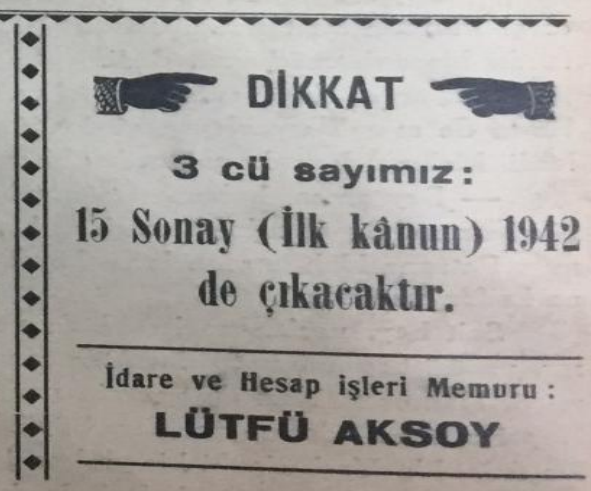

Cumhuxiyet Matbaasx - 20 Kuxus

Ek-2: Gök-Börü Dergisi 1. Sayı Arka Kapağı 


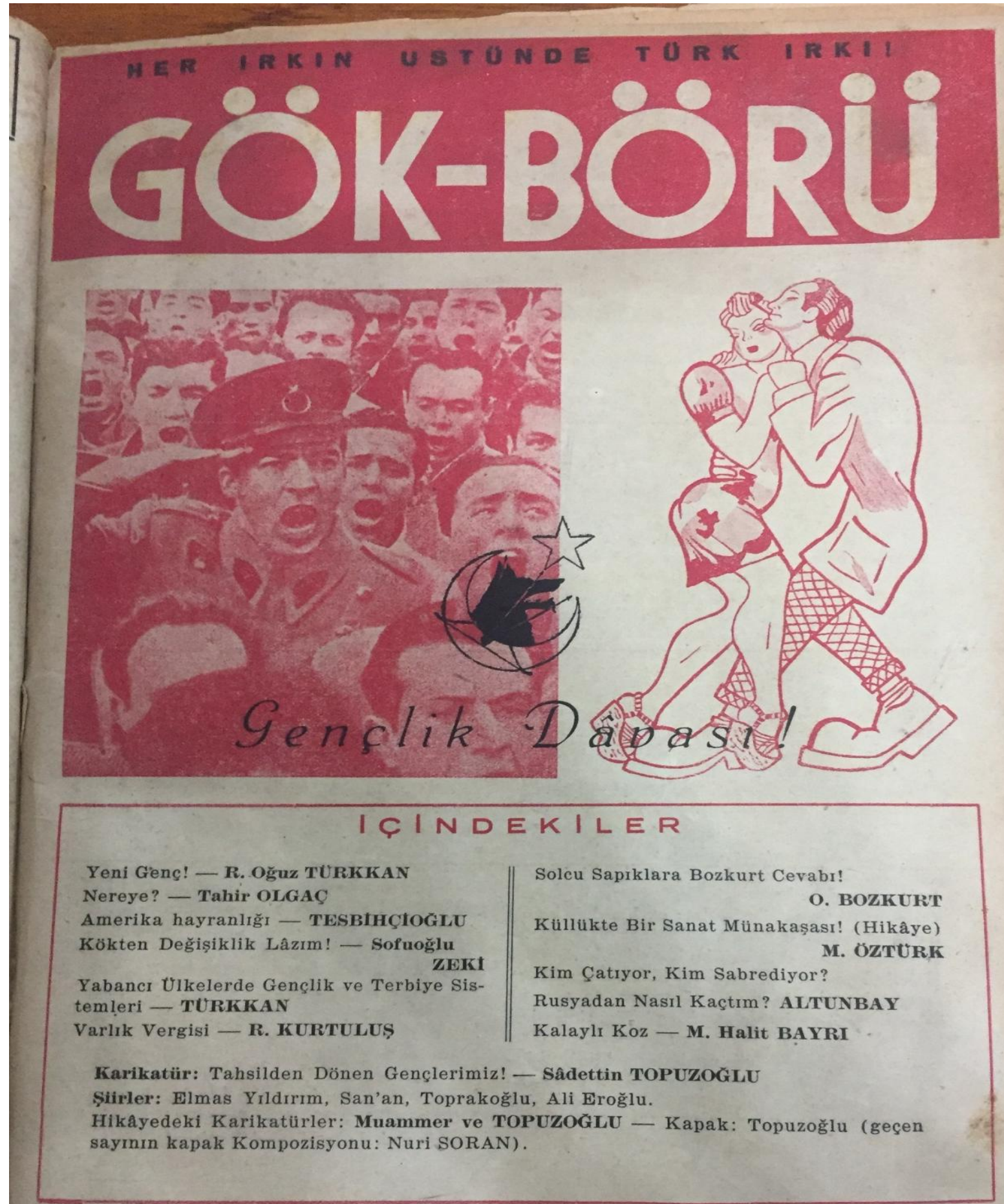

\section{I. $1943 \cdot S A Y I: 5$}

Ek-3: Gök-Börü Dergisi 5. Sayı Kapağı 


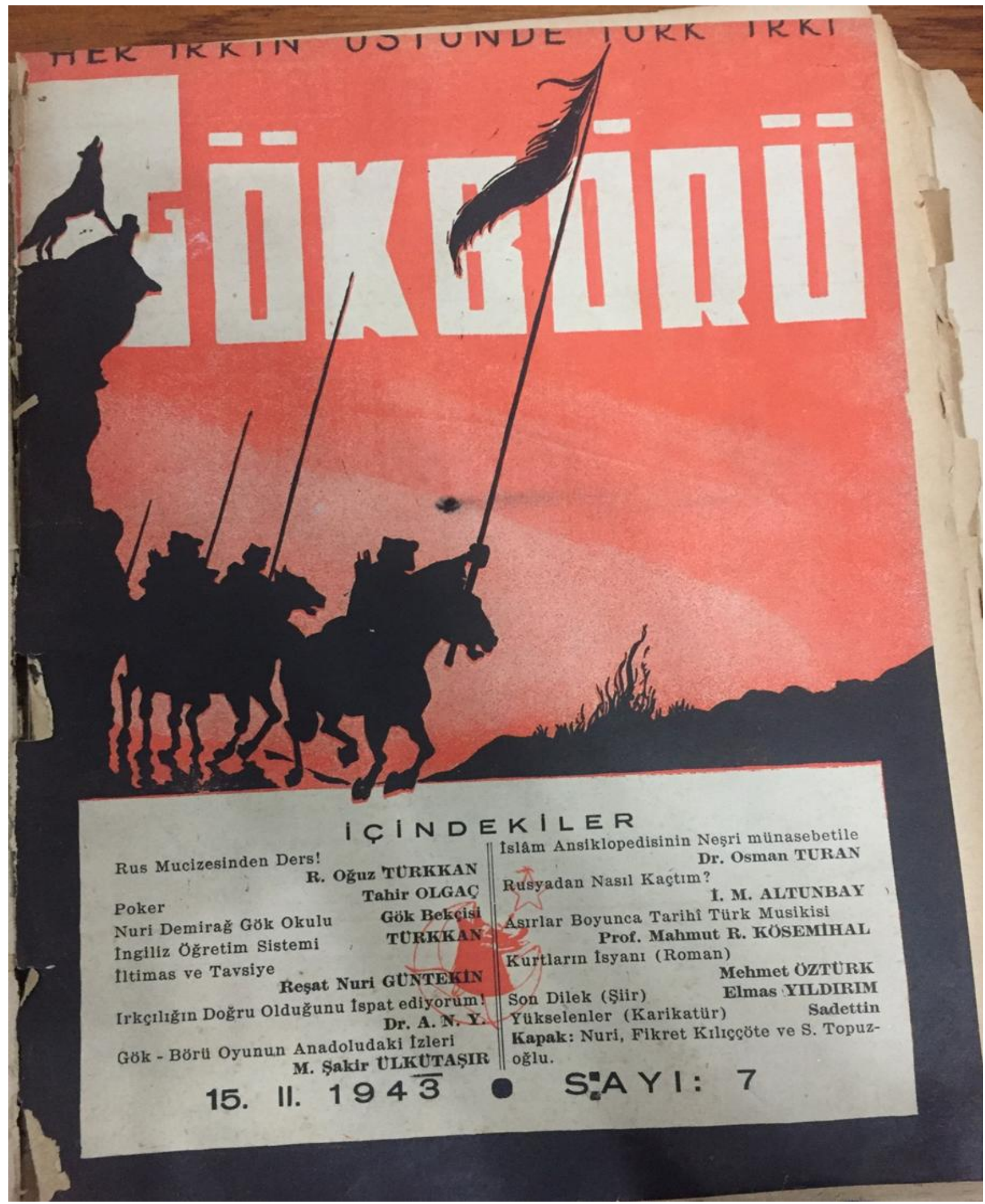

Ek-4: Gök-Börü Dergisi 7. Sayı Kapağl 

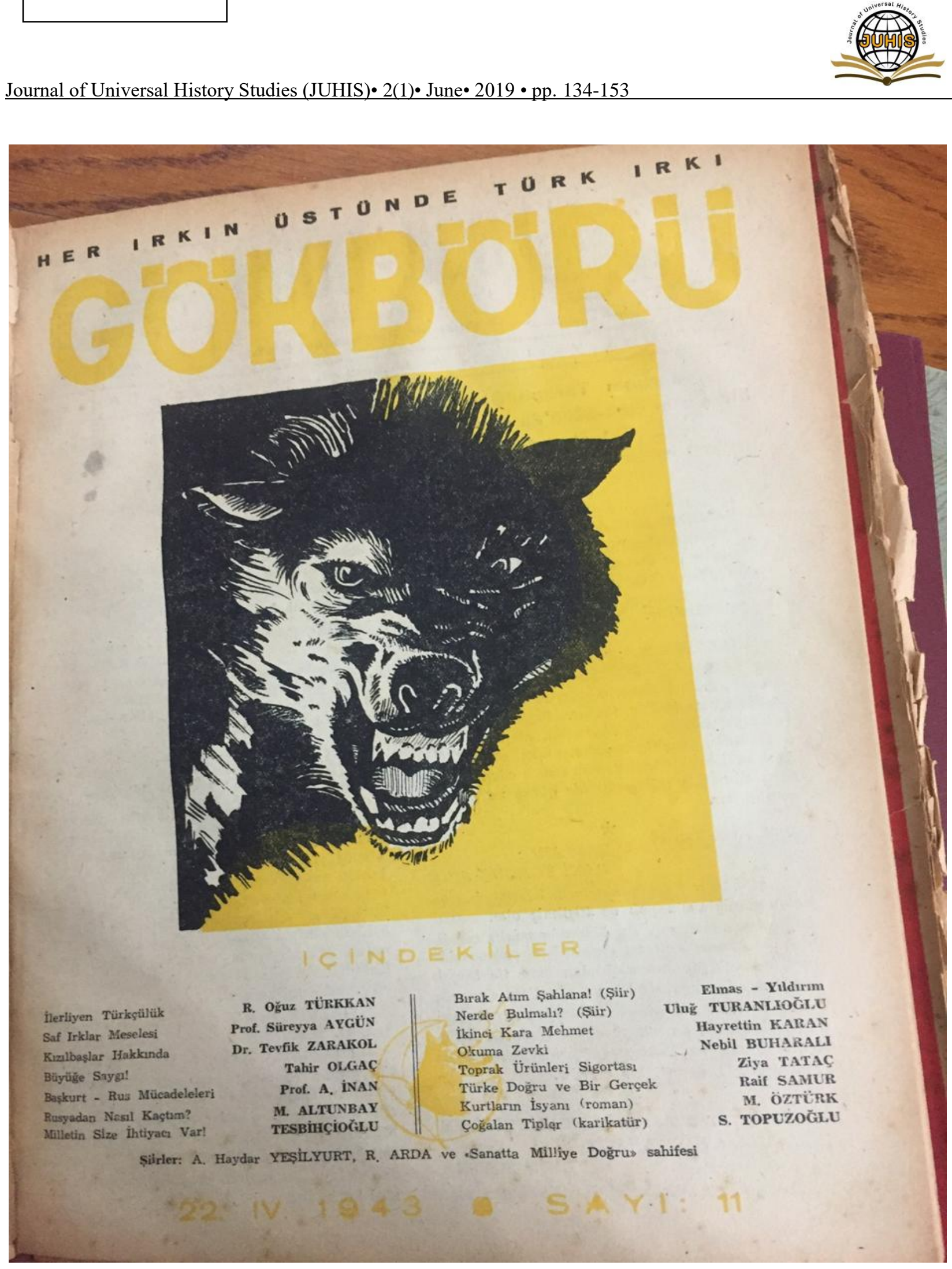

Ek-5: Gök-Börü Dergisi 11. Sayı Kapağı 


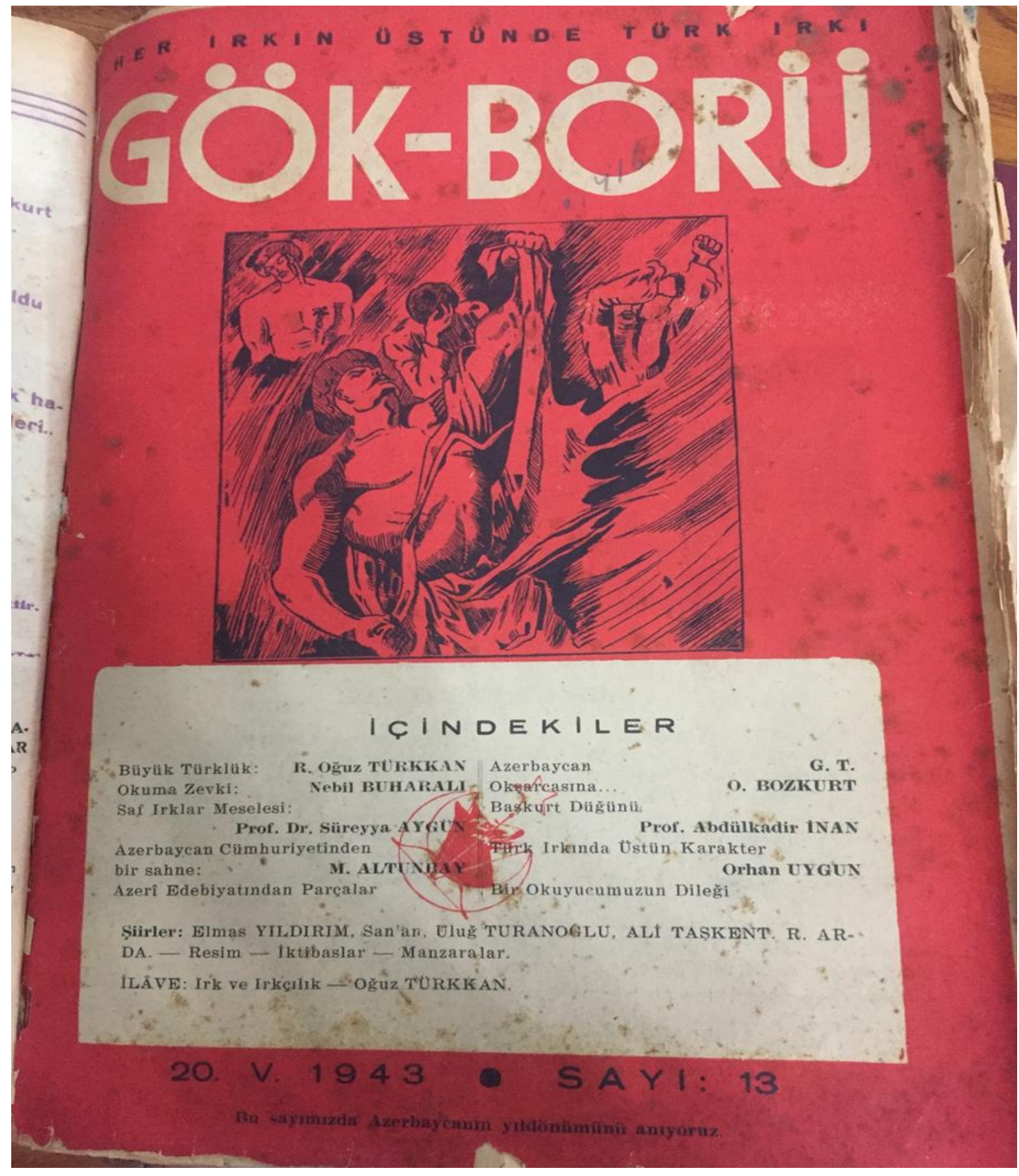

Ek- 6: Gök- Börü Dergisi 13. Sayı Kapağı 